\title{
Ethical Assumptions: A Criticism against Modern Pragmatism
}

\author{
Maximiliano E. Korstanje ${ }^{1,2, *}$ and Geoffrey Skoll ${ }^{3}$ \\ ${ }^{1}$ University of Palermo, Argentina \\ ${ }^{2}$ Fellow at CERS University of Leeds, UK \\ ${ }^{3}$ State University of New York At Buffalo, USA
}

\begin{abstract}
The advent of neoliberalism in the early 1970s marked a new age for ethical practices. Although pragmatism as an approach to ethics pre-dated neoliberalism, the neoliberal approach to political economy ushered in a new kind of pragmatism, owing little to Jeremy Bentham, even less to the American philosophical pragmatists Charles S. Peirce, William James, and John Dewey. Today's pragmatism has permeated the penal systems of the central countries of the world capitalist system. A new ethics emerged, a neopragmatism. Acts came to be judged by their effects and not by the motives that led to the actions. This altered the doctrine of Abrahamic religions, and led to the disappearance of forgiveness as a moral good.
\end{abstract}

Keywords: Pragmatism, Forgiveness, Crime control, Securitization Process.

\section{INTRODUCTION}

After Hobbes, sociology and political philosophy acknowledged the power of the Leviathan, in which the state uses violence to deter crime as a pre-emptive mechanism of social control. In order to prevent the Hobbesian war of all against all, a transcendent agency (the state) monopolizes violence over a community. In modern political theory citizens were debarred from killing each other, while the state coordinated efforts to re-educate criminals who threaten the order of society (Beccaria, 1764 /1995; Garland, 1985; and MerleauPonty, 1964;). The present discussion is occasioned by media construction of local crime, and long after the rise and consolidation of the nation-state of Hobbes's time. Jonathan Simon (2007) called it governing through crime. The United States declared a war against crime to cover a much deeper crisis that eventually would lead to the decline of trust in democratic institutions. Richard Nixon used his presidency to create a message of fear to manipulate public opinion.

Maximiliano Korstanje (2015) pointed out that the tactic of governing through crime was accompanied by the introduction of ethical transformations whereby people are not judged by their intentions but by the effects of their actions. The present essay explores how the advance of late capitalism not only altered the mode of production, but also instilled a new way of interpreting social relations. The Western legal system, inherited from Greece, requires a separation between

*Address correspondence to this author at the University of Palermo, Argentina; Fellow at CERS University of Leeds, UK;

E-mail: maxikorstanje@hotmail.com judges and suspects. The judge should be disinterested; it recruits citizens whose objectivity would be assured by their lack of familiarity with suspects. The tragedy of Oedipus, discussed by Christopher Menke (2009) depicts the impossibility for the guilty to be judges and executioners. Under modern, but not neoliberal, jurisprudence, if Oedipus had a just trial, he would have been absolved of his crime, because modern criminal legal theory requires conscious intent. But in the psychological law of guilt, Oedipus takes the justice into his own hands and therefore becomes criminal, judge, and executioner (Menke, 2009). This classic myth fits the neoliberal jurisprudence, and helps explain how moral pragmatism has changed our sense of forgiveness under late modern capitalism.

\section{PRELIMINARY DISCUSSION}

One of the pioneers in studying the intersection of crime social order was Emile Durkheim. He proposed to think of crime as a social phenomenon, which reflects and codifies rules of reciprocity. For Durkheim, offenses play a dual role. They set the boundaries of norm-governed behavior symbolized by the power of law, and by their articulation of punishment. Occasional crime and its punishment intensify the solidarity in a society (Durkheim, 2001; 2014). However, in the time Durkheim wrote, things were different than today. Durkheim's era was dominated by an individualistic, Spencerian survival of the fittest ideology, but in the modern era, after the Second World War, the welfare state came to be the accepted norm in the West, especially in Europe, although less so in the United States. Government was supposed to orchestrate welfare for all citizens, maximizing pleasure and 
minimizing suffering. This modernist ideology is underpinned by a Fordist mode of production which valorizes mass production and efficiency which leads to generalized prosperity. The modernist, Fordist doctrine of security rests on an interesting paradox, as Cavaletti (2010) observed. The more the state becomes the instrument of security, the more vulnerable the citizens feel. Under late capitalism, however, industrial cultures are experiencing a much deeper revolution in their symbolic cores, which affects the current views on the penal system, education, and the doctrine of the welfare state (Inglehard, 1997). One of the aspects that characterizes late modernity coupled with neoliberal doctrine is that citizens are co-managers of their own destiny. The social imaginary judges the good citizen as the person who is financially able to face and mitigate the risks of life while vulnerable people, though protected, are marked as undesired guests. All these changes came from a new decentralized way of production, where collectivism sets the pace to individualism. Postmodern, neoliberal penal policy is based on the conviction that criminals are beyond rehabilitation, and nothing works to reintegrate them into society (Raynor and Robinson 2009). The former, modernist policies that treated law breakers as agents to rehabilitate, or even re-educate, have been replaced by policies that treat offenders as irremediable psychopaths, who are dangerous for society, and whose rehabilitation seems to be an impossible project.

\section{THE ROOTS OF CRIMINAL MINDS}

In The Child of a Moral Philosopher. Lawrence Kohlberg (1970) acknowledged that the adoption of ethics varies according to developmental stages of Childhood. In early childhood, we understand acts or events only in terms of their effects on us. This puerile, pragmatic point of view evolves to a less solipsistic view where one estimates that effects have consequences and vice-versa. In this vein, Erik Erikson (1996) notes how Puritan reformers, once they arrived in America established a system of heavy punishment for those deviants who did not adhere to the status quo. The allegory of a city on a hill suffused the Puritan inspired colonists of New England in America. The new society was to be a shining beacon to the world because of its moral probity. From the outset, the founders of what was to become the United States developed the idea that "the Other" which cannot be disciplined, would represent a real threat for social cohesion. Although not so thoroughly articulated, the slave-based plantation economy of the Old South had a parallel view. American indigenes and slaves of
African origin provided the models for the anti-social. According to the Puritanical, Calvinist tradition guilt does not come from a deviant act; it reflects the condition of the soul and its propensity to break the law. Therefore, this ethos sees crime not as the result of an atmosphere of violence and hate, but as manifestation of inherent criminality. In contradistinction to this seventeenth century ideology, the modern conception of crime and criminality views criminals, and all other citizens, as self-interested individuals oriented to maximize their gains while minimizing the costs. This rationalist concept of human behavior guided modern criminology. Essentially utilitarian, modernist penology focused on the disciplined nature of punishment to avoid conditions of delinquency. With certain variations, penal policy treats individuals who are presented with options that assume the self-interest of the subject (Agnew, 2012; 2013; 2014).

The current studies of criminality include a combination of social and psychological predispositions. In the penal system, the classification of offenders produces a criminal portfolio, in which each person is catalogued by their crime. No matter how they act, or how remorseful they feel, this record will accompany them their rest of their lives (Agnew 2014). With the end of a rehabilitative policy they have almost no choice but to adopt crime as a matter of identity. The nation state deploys a set of differential disciplinary mechanisms to prevent crime, but without the aim of educating or rehabilitating offenders. Rather, they are labeled as forever delinquent (Thomas et al. 2014).

Recently, Zygmunt Bauman and David Lyon (2013) noted the postmodern tendency to valorize security over other cultural values. Society, according to them, is facing a climate of securitization, which also allows the adoption of surveillance as a sign of belonging. The citizen is caught by two social developments. On one hand, it is important not to be abandoned or symbolically excluded from the net of consumers; and of course this represents one of the most frightening aspects of being in relation with others in postmodernism. Social relations are replaced by relations of consumption. The other is the continual propaganda of increasing crime, even in the face of all data that crime is decreasing. Globalization has shrunk the world and made crime appear to be an immediate threat by continual representations of it it. In fact crime and criminality have become simulacra, except for those crimes committed by ruling elites. 
Derek Jeffreys (2013) has noted the convergence of general and specific deterrence. General deterrence aims at crime prevention by holding $u$ the possibility of punishment. Specific deterrence is designed to prevent an offender from re-offending. The growth of solitary confinement and super maximum security prisons ostensibly serves both kinds of deterrence. The Argentine sociologist, Pilar Calverton says that the expansion of neoliberalism in other agrarian economies was achieved thanks two different but complementary policies. The enactment and administration of laws to control lower class groups in the context of ghettoization was coupled with the imposition of lengthy prison terms. The goal of these policies was to exert a total control over citizens.

For Calveiro, states are not working to reduce crime, because crime has become a commodity to expand the hegemony of elite over potentially dissident groups. Without the fear instilled by terrorism or crime, as Korstanje puts it (2015), many of the neoliberal policies would be rejected by ordinary citizens. Material asymmetries inherent in modern capitalism can jeopardize the interests of privileged groups when the lower classes gain consciousness. In order to maintain hegemonic legitimacy, the elite use fears of crime and terrorism to forestall working class revolt.

\section{HOW CRIMINOLOGY IS CHANGING OUR ETHICS}

Recent criminology has tended to focus on the behavior of offenders, and retreated from giving attention to social influence. Nonetheless, when it comes to gang formations, social influence is indispensable for adequate understanding, as the role of peers and self-esteem is vital in the configuration of gangs and potential offenders (Viki and Abrams, 2013). Since people want to be loved, or even accepted, they will adjust their course of actions to the in-group rules. Key factors such as social status, peer esteem, and social recognition are not treated or even recognized as essential in programs for crime prevention. Gangs captivate the spirit of teenagers most of them escaping from disorganized homes, and so it is not very hard to think that any process of securitization based on heavier punishments is bound to fail. If psychological deprivations are rechanneled towards the quest of peer-esteem, it is tempting to say that groups whose members come from homes of weaker ties are more vulnerable to delinquency than other groups (Wood and Aleyne, 2013).

Recently, a new academic wave that takes the best of the Chicago School with Marxist studies emphasizes the influence of the social environment. Joanne Thakker (2013) points out that criminals, like us, seek social recognition to enhance their self-esteem. Depending on how the in-group valorizes their members and the rules they honor, the subject can be attracted by social belongingness with or without criminal activity. Analysts should pay more attention to the influence of group membership to captivate candidate for rehabilitation. Multiple factors such as culture, religion, community cohesion explain why some programs have backfired while others have succeeded. The question whether rehabilitation is useful or not for the modern society has been recently trivialized by policy makers.

One effect of modern capitalism has been to rationalize social relations to a means-end kind of ethos. In contrast, medieval societies, which were based on a tradition-oriented logic, adopted the concept of forgiveness as a gift. As a result of this, the medieval peasant not only was attached to the past, but valued tradition as a way to connect with neighbors. David Harvey has said that the social decomposition accelerated by postmodernity has led to ruptures in ethics. In part, this is because, post-modern consumers are not interested in coping with past. They are concerned only in forecasting the future (Harvey, 2004). As a cultural project, post-modernity neglected the past. It focuses on the effects of events, not their reasons. The rise of a post-modern ethic concentrates on effects not causes. It penalizes deviance without understanding it. In a world where effects are more important than reasons, the concept of forgiveness as it was formulated by Abrahamic religions is changed to a much wider process of victimization. The voices of victims today penalize offenders, but do nothing to compensate either the immediate victim or the social fabric.

\section{SHOULD WE FORGIVE OUR OFFENDERS?}

Richard Bernstein (2006) uses the symbol of Auschwitz as the epitome of human cruelty. Once the Nazis arrived at the final solution, the idealized concept of the law vanished. Bernstein points to the role played by Nazi academicians in undermining ethics as something external to human judgment. Contextualized in the culture as well as the rules of society, what is good or bad depends on the power of privileged groups. Unless otherwise resolved, this kind of pragmatic so-called realism leads to Nazi thought where the vulnerable Other can be diminished to the degree of untermensch or as Giorgio Agamben (1995) 
put it, "bare life" without any moral qualms. Villains can move in this world while following the current law, which morality calls law breaking. The appalling crimes against Jews during WWII became feasible by the moral relativism induced by the underside of the Enlightenment where rational calculation becomes more important than human life (Horkheimer and Adorno 1947). The meaning of radical evil corresponds with the decline of criticism that affects the autonomy of decision making process (Bernstein 2006).

In contrast with Bernstein, Peter Lang says Auschwitz is something other than evil incarnate. In contemplating the Nazi genocide as a radical evil, we might view the Nazis as demons, and therefore outside human law. Lang's contributions to the present discussion lies in the fact that the demonization of criminals undermines their responsibility as humans who hurt others. Though, Bernstein cannot be framed as a pragmatist philosopher, his position is not so different from Kekes who says evil should be defined in terms of the evil doer. In opposition to Bernstein, Kekes maintains that any rational agent may commit serious crimes under exigent conditions. In this respect, Kekes develops a philosophical model in which acts are judged by their effects, not their intents. This pure objective guilt abrogates the religious view that emphasizes the inner life. Religion may be able to explain death, but, Kekes observes, it has failed to account for the root of evil without recourse to imaginary creatures such as demons. The Abrahamic religions include an immanent contradiction between human free will divine agency. Offenders may appeal to reason to justify their acts, or cover their real intentions, but not because they feel guilt.

Reason and law often seem inseparable, but only appear as such bcause of the reigning ideology of a society. The law consists of texts. In the case of nonliterate societies, the texts are oral, maintained by memory, and often performative. Literate societies maintain the law in written texts. Both kinds of legal texts express, formally, normative aspects of ideology. As ideologies change through time, the texts of laws may change, or the texts may stay the same, but receive different interpretations. Whatever kind of texts, oral or written, the legal expression of ideology is made of signs, as is ideology as a whole. Ideological, and therefore legal, signs partake of the ongoing social semiotic, and consequently they express meaning. The signs are material, whether performative or written. That is, they have a physical, observable form. They are not mere ideas, not Platonic forms.
This fungibility of ideological signs makes them refracting and distorting media. Ruling elites strive to impart an eternal character to such signs, to extinguish or occlude the social value of struggles indexed by the sign, and to make the sign uniaccentual (Vološinov 1973:23).

In actual fact, each living ideological sign has two faces, like Janus. . . This inner dialectic quality of the sign comes out fully in the open only in times of social crises or revolutionary changes. In the ordinary conditions of life, the contradiction embedded in every ideological sign cannot emerge fully because the ideological sign in an established, dominant ideology is always somewhat reactionary . . . so accentuating yesterday's truth as to make it appear today's. (Vološinov 1973:23-24

Herman Bianchi's Tsedeka, Robert Cover's paideic strategy, and rabbinic discourse share important precepts. They all treat law as pedagogic instead of controlling and punitive. "Obedience is correlative to understanding. . . . Interpersonal commitments are characterized by reciprocal acknowledgment" (Cover 1983:13). The uncontrolled character of meaning in rabbinic discourse "exercises a destabilizing influence upon power" (Cover 1983:18).

Bianchi (1994) described a eunomic approach to crime control that contrasts with the current repressive system. He maintains that the repressive system is anomic. Anomia, according to Bianchi is not normlessness, as Durkheim's usage is usually interpreted. Citing the rabbinic tradition about the Torah and reminding the reader that Durkheim's father, grandfather, and great grandfather were rabbis; Bianchi likened anomia to ignorance of the law. He then contrasted the anomic with the eunomic approach to criminal justice on thirteen axes: disruptive versus communicative, vertical versus horizontal, inquisitorial versus responsive, informative versus educative, provocative versus invocative, servo mechanic versus organic, frustrative versus therapeutic, irrational versus rational, enemy versus opponent, criminalization versus real law, dysfunctional versus functional, stigmatization versus liberation, and ritualism versus expiatory (Bianchi 1994:58-70).

The repressive anomic system disrupts all social relations by removing offenders. A eunomic system promotes communication similarly to that envisioned by 
restorative justice. The anomic repressive system organizes justice vertically. A eunomic system supports horizontal social relations. The anomic system rationalizes threats, incarceration, and even torture in a disingenuous search for a limited and heavily rationalized version of the truth. Eunomic criminal justice avoids making truth claims, and instead demands responsibility from all citizens. The repressive system partly justifies punishment as deterrence, whereas the eunomic system aims at education: "The normative learning process cannot be fostered by fear of pain, only by identification with good examples" (Bianchi 1994:61). Psychologically, punishment provokes anger and resentment. A eunomic system seeks not to provoke but invokes offenders to resolve the conflicts they have caused.

One of Bianchi's most relevant contrasts is that of the servomechanism versus organic. Servomechanisms are control devices in which smaller devices control larger ones. "A repressive crime-control system is a kind of servomechanism in a large political power system, the modern state" (Bianchi 1994:62). The eunomic approach is organic in that it seeks resolution of social conflicts, dissolves stratifications, and neutralizes class and status divisiveness.

The frustrative versus therapeutic distinction refers to the same kind of personal change among victims and offenders as that sought by restorative justice. The repressive system treats criminals as enemies in ways stated by George Herbert Mead in 1918. Eunomic systems treat lawbreakers as opponents whose humanity cannot be doubted. In a similar vein, the criminalization versus real law contrast notes that the repressive system does not aim to control crime but sustain the status quo of the hierarchic system of social stratification. A eunomic system avoids this classbased control system by demanding broad participation in every aspect of justice. The anomic repressive approach has long been identified as dysfunctional for crime control. Eunomic approaches are more likely to be functional because they appeal to people's capacity for conflict resolution. The repressive system unabashedly stigmatizes criminals. Eunomic systems liberate offenders from guilt because they get a chance to make reparations. Finally, the repressive system relies on ritual to legitimize its actions. Eunomic criminal justice demands expiation.

This relates to the justification for torture. An argument in favor of torture is part of the lesser evil doctrine. In case of terrorism torture came to be justified to prevent the next terrorist attack. Unfortunately for torturers proponents, torture does not prevent the next attack, because the tortured only says what $\mathrm{s} / \mathrm{he}$ thinks the torturers want to hear. Therefore, the US use of torture did not prevent future attacks; it merely justified actions that had already been planned by the US military. This represents the first ontological proof. Idealists are wrong in their conception of human will. The context of torture as well as idealized reasons should be ignored, Kekes adds, if we need to achieve justice. As rational agents they are subject to trial by what has been done.

Understanding that self-esteem struggles with external constraints to maximize achievement to reduce potential costs, there is no reason to imagine that ethics, as idealists assume, restricts evildoers from hurting others.

Kekes' argument must be taken with some serious caveats. Harry Frankfurt (2009) pointed to the limitations of pragmatism for understanding free will. Of course, people are responsible for their behavior only when their decisions are made in context of liberty, and liberty is and has been in short supply in modern times. We do the correct thing, because we proactively elect to do it. In the same way, we cannot be blamed if we hurt others without any type of intention, for example in an accident. Detractors of free-will related theories are prone to blame decision-makers for effects they had no intention or never prefigured in the mind. Imagine meanwhile driving correctly by the roads I ran a boy with the car. I stop the vehicle and pick up the victim directly towards hospital, but in the meantime, by after the wounds, the victim dies. To what extent the driver is responsible or is an evil-doer?

The neoliberal, pragmatic ethics project has some explaining to do about the hegemony of instrumentalism it has rationalized. Slavoj Zizek offers a radical critique on the configuration of evil, which, with a false urgency, commodifies the Other's suffering. In the age of globalization, maximization of profits has become the ultimate value, the measure of what is good and bad. Companies like MacDonald's make post-disaster donations to communities to enhance their public relations image in the service of greater sales revenue. Disasters present the perfect excuse to offer their own products to the survivors (Zizek 2009). Maria Pia-Lara (2009) criticizes Zizek, because she says his view of ethics reinforces a much deeper process of desensitization that leads to depersonalization. Nonetheless, her criticism on Zizek 
is not total. For the new postmodern ethics religion remains the main obstacle to overcome. Voluntarily or not, many philosophers who are critical of modernity reject the possibility of incorporating ethics from Abrahamic religions. Not surprisingly, Catholic priests are portrayed as pedophiles while Muslims are synonymous with terrorists. Postmodern ethics need to destroy religion to eradicate the figure of forgiveness and remorse. Far from being dogmatic, Zizek clarifies in his book The Dwarf and the Puppet. He points to the perverse core of Christianity as its anthropomorphism where Gods become humans. Moreover, it has a reactionary core to debar other religions. In this view, salvation of the soul does not come from acts of Christ but by the fact he was cheated by Judas. In doing so, treachery and not charity is the main reason why Christianity is conducive to capitalism. Without treacherous Judas, Christ never would be tortured, killed, and resurrected. The sensible world shows a combination of violence (as Judas betrayed Christ) and love. Similarly, the administration of forgiveness reveals an ethical contradiction. Zizek understands that forgiveness, regardless of whether the sinner is really repentant, reinforces a logic whereby the guilty are used to discipline others. One of the ideological messages articulated by Catholic Church over the world, per Zizek, is that forgiveness poses a precondition to enter in Heaven. Far from being real he sees in forgiveness a reason to continue hurting others.

Neoliberal instrumentalism, as an ethical system, rests on shaky foundations. Abrahamic religions stem from what anthropologists know as sedentary societies, administered by a pastor who protects his shepherds. Sedentary societies are distinguished from huntergatherers or nomadic peoples by, among other things, the way they interpret the Other. In sedentary societies intra-tribal violence or conflicts among lineages is regulated by rituals of forgiveness and gift-exchange. Without these institutions, offenders and offended will struggle in cycles of blood feuds. Conflict in sedentary, kinship-based tribal societies needs regulation, not through law and litigation, but through, religious forgiveness or paying tributes to victims' kin.

Modernity and capitalism eradicated the institutions of forgiveness to make way for autonomous individualism and concomitantly weaken social bonds in traditional societies. In the late capitalism, where governments opt for the tactic of governing through crime, not surprisingly, pragmatism offers a rationalization for why forgiveness should be left behind. Forgiveness reduces efficiency, it $s$ therefore not practical. Instead crime comes to define whatever interferes with profits and the accumulation and concentration of capital. Making law and order into commodities enhances. Undoubtedly we are living in an atmosphere where the disciplinary mechanisms of states are designed to repress potential dissenters to help ensure the reproduction of the social structure, relations of production, and so the elite keep their authority.

\section{CONCLUSION}

Te radical rupture occurred in the latter part of the last century was marked by the onset of postmodernity, has brought a new ethic, in which penalties are indiscriminately applied to discipline minorities, and criminals are doomed (stigmatized) for the rest of their life. They are automatically excluded from the promises of market. In doing so, the circulation of goods and their value of exchange arise because so-called good citizens want security. Neoliberal markets fill this gap by offering products associated with security. The state increases its punitiveness, ostensibly to control violence, but really aimed at the smooth function of the market to benefit owners of capital. In addition, today we face a new policy applied by the mass media in which events are not judged by the social context of crime, but only by evaluating their effects. Neoliberal ideology has striven to delete class consciousness from higher education, especially in conservatories of legal knowledge and practice. Legal education constructs a veil of obfuscation around the fact that law is designed to serve the interest of the ruling class. Criminals work as mirror of our own society; they are our repressed dark side. Analyzing the criminal world is the best ways of understanding our own miseries. Not surprisingly, this society strengthens the disciplinary penalties over deviants by emphasizing their faults. It rejects the possibility to forgiveness, blaming the victim, while crimes of the ruling class, from bank fraud, gun running, narcotics dealing, up to aggressive war and genocide are swept under the rug. We live in a society of crime and terror that promotes the value of commodities' exchange value.

\section{REFERENCES}

Agamben, Georgio (1995/1998). Homo Sacer: Sovereign Power and Bare Life. Translated by Daniel Heller-Roazen. Stanford, CA: Stanford University Press.

Agnew, R. (2012). Reflection on "A Revised Strain Theory of Delinquency". Social forces, 91(1), 33-38. http://dx.doi.org/10.1093/sf/sos 117

Agnew, R. (2013). Integrating Assumptions about Crime, People, and Society: Response to the Reviews of toward a Unified 
Criminology. Journal of Theoretical \& Philosophical Criminology, 5(1), 74.

Agnew, R. (2014). "Social Concern and Crime: moving beyond the assumption of simple self-interest". Criminology, 52(1), 1-32. http://dx.doi.org/10.1111/1745-9125.12031

Bauman, Z. \& Lyon, D. (2013) Liquid Surveilance. Buenos Aires, Paidos

Beccaria, Cesare. 1764 (1995). Of Crimes and Punishments. Translated by Richard Bellamy, Richard Davies, and Virginia Cox. New York: Cambridge University Press.

Bernstein, R. (2006) Radical Evil. A philosophial interrogation. Buenos Aires, Ediciones Lilmod

Bianchi, Herman. 1994. Justice as Sanctuary: Toward a New System of Crime Control. Bloomington, IN: Indiana University Press.

Calveiro, P. (2009) Violencias de Estado: la Guerra antiterrorista y la guerra contra el crimen como medios de control global. Buenos Aires, Siglo XXI

Cavalletti, A. (2010) El Mito de la Seguridad: la ciudad biopolítica. Buenos Aires, Adriana Hidalgo Editora.

Cover, Robert. 1983. "Nomos and Narrative." Harvard Law Review 97: 4-68.

Durkheim, E. (2001). The Rules of Sociological Methods. México, FCE.

Durkheim, E. (2014). The division of labor in society. New York, Simon and Schuster.

Erikson, K. T. (1966). Wayward puritans: $A$ study in the sociology of deviance New York: Wiley.

Frankfurt, H. (2009) The importance of what we care about: philosophical essays. Buenos Aires, Katz

Garland, D (1985) Punishment and Welfare: a history of penal strategies. Aldershot: Gower.

Harvey, P. (2004). The Condition of Postmodernity. Buenos Aires, Amorrortu Editores.

Horkheimer, Max and Theodore Adorno. (1947/2002). Dialectic of Enlightenment: Philosophical Investigations. Edited by Gunzelin Schmid Noerr; translated by Edmund Jephcott. Stanford, CA: Stanford University Press.

Inglehart, R. (1997) Modernization and Postmodernization. Cultural, Economic and political change in 43 Societies. New Jersey, Princeton University Press.

Jeffreys, D. (2013) Spirituality in Dark places. The ethics of solitary confinement. New York, Palgrave Macmillan. http://dx.doi.org/10.1057/9781137311788
Kohlberg, L (1970) The child as a moral Philosopher: reading in developmental psyhology today. California, CRM Books.

Korstanje M. E (2015) A difficult World. Examining the roots of Capitalism. New York, Nova Science Publshers.

Mead, George Herbert (1918). The Psychology of Punitive Justice. American Journal of Sociology 23(5): 577-602. http://dx.doi.org/10.1086/212795

Menke, C. (2009) Tragic Play, irony and theater from Sophocles to Beckett. New York, Columbia Universty press.

Merleau-Ponty, M. (1964) Sense and Non Sense. Illinois, Northwestern University.

Lang, B. (1999). The Future of Holocaust, between history and memory. Ithaca, Cornell University Press.

Pía-Lara, M. (2009) Narrar el Mal: una teoría postmetafisica del juicio reflexionante. Barcelona, Gedisa.

Raynor, P \& Robinson G (2009) Rehabilitation, Crime and Justice. London, Palgrave-Macmillan.

Simon, J. (2007). Governing through crime: How the war on crime transformed American democracy and created a culture of fear. Oxford, Oxford University Press.

Thakker, J (2013) "Considering group membership for effective treatment" ". In Crime and Crime Reduction: the importance of group processes. Edited by J. L Wood \& T A Gannon. London, Routledge, pp. 177-198

Thomas J. et al. (2014) "Early Contact with the Criminal Justice System and Intellectual Functioning as Risk factors for Violent and Chronic Adult Offending". Western Criminology Review. Vol. 15 (1): 34-50

Viki G T \& Abrams D (2013) "The Social Influence of groups on individuals". In Crime and Crime Reduction: the importance of group processes. Edited by J. L Wood \& T A Gannon. London, Routledge, pp.3-33

Vološinov, Valentine Nikolaevič. 1973 (1930). Marxism and the Philosophy of Language. Translated by Ladislav Mateka and I. R. Titunik. New York: Seminar Press.

Winnicott, D. (1965) The Family and the individual development New York, Basic Books.

Wood, J L \& Alleyne, E. (2013) "Street Gangs: group processes and theoretical explanations". ". In Crime and Crime Reduction the importance of group processes. Edited by J. L Wood \& T A Gannon. London, Routledge, pp. 34-55

Zizek, S. (2005). The Dwarf and the Puppet. The perverse core of Christianity. Buenos Aires, Paidos

Zizek, S. (2009). Violence. Buenos Aires, Paidos.

Received on 04-03-2016

Accepted on 28-03-2016

Published on 26-04-2016

\section{DOI: http://dx.doi.org/10.6000/1929-4409.2016.05.06}

(c) 2016 Korstanje and Skoll; Licensee Lifescience Global.

This is an open access article licensed under the terms of the Creative Commons Attribution Non-Commercial License (http://creativecommons.org/licenses/by-nc/3.0/) which permits unrestricted, non-commercial use, distribution and reproduction in any medium, provided the work is properly cited. 